\title{
Sonographic Correlation of Liver Dimensions with Anthropometric Variables in Apparently Healthy Pediatrics in Kano Metropolis, Nigeria
}

\author{
${ }^{1}$ Mohammed Sidi, ${ }^{1}$ Ahmad Safiyanu Idris, ${ }^{2}$ Aliyu Abdullahi Hassan
}

${ }^{1}$ Department of Medical Radiography, Faculty of Allied Health Sciences, College of Health Sciences, Bayero University Kano

${ }^{2}$ Radiology department, Aminu Kano Teaching Hospital.

Email: xray2rad16@gmail.com

\begin{abstract}
Accurate measurement of liver size allows for the diagnosis of various liver pathologies. Establishing normal liver size and how it is influenced by anthropometric variables is critical in diagnosis and determining the treatment method for the underlying liver pathology. This study was aimed at establishing the relationship between liver dimensions and anthropometric variables. The study was a cross-sectional study conducted in some selected hospitals in Kano Metropolis, Nigeria. Four hundred and twenty-six apparently normal pediatric subjects were studied within the age range of 0 $<18 y e a r s$. The liver was examined with the patient in supine position, both the cranio-caudal and antero-posterior liver dimension were obtained through the mid clavicular line in longitudinal and transvers planes respectively. Both descriptive inferential statistics were employed for the data analysis. Statistical Package for Social Sciences (SPSS) was used and $p>0.05$ was set as significance level. There was a statistical significant strong positive correlation between cranio-caudal dimension and age, height, weight, BMI and BSA in $<1$ month $>12$ month age group $(r=0.74, p=0.000 ; r=0.86$, $p=0.000 ; r=0.64, p=0.000 ; r=0.74,0 . p=000$ and $r=0.53, p=0.000$ respectively for males and $r=0.60$, $p=0.000 ; r=0.61, p=0.000 ; r=0.59 ; p=0.000 ; r=0.81, p=0.000$ and $r=0.66, p=0.001$ respectively for females). Also, in the same age group both male and female subjects show significant strong positive correlation between anterior-posterior dimension and BMI $\mathcal{E} B S A:(r=0.67, p=0.000, r=0.67$, $p=0.000$ respectively for males and $r=0.69, p=0.000, r=0.77, p=0.000$ respectively for females). This study reported that anthropometric variable such as age, height, BMI and BSA is positively correlated with both cranio-caudal and antero-posterior liver dimension.
\end{abstract}

Keywords: Ultrasound, Liver, Cranio-Caudal, Antero-Posterior, Dimension.

\section{INTRODUCTION}

Abdominal ultrasonography is a widely used imaging technique for liver examination. Noninvasiveness, inexpensive, convenience, availability and lack of ionizing radiation are among its advantages over computed tomography (CT) as well as Magnetic Resonance Imaging (MRI) (Ozmen et al., 2018). Pediatrics age group stretches from newborn to adolescents; neonate, infant, toddler, preschool, school age and teenager. Pediatrics are 
vulnerable to infections and immune diseases (Lissauer et al., 2015). The Liver is a dual organ vested with many functions including both secretory and excretory functions. It is the largest gland in the body, weighing about $1.5 \mathrm{~kg}$ in man (Simbulingam and Simbulingam, 2012). It comprised of two functionally independent right and left lobes, defined by the arterial distribution. Each is supplied by the right and left portal veins and the right or left hepatic arteries and drained by the right or left hepatic duct (Ryan, 2004). The functions of the liver include; metabolic, storage, synthetic, excretory, hemopoietic, defensive, detoxification, formation of bile, heat production, inactivation of hormones and drugs (Simbulingam and Simbulingam, 2012).

Hepatomegaly is a frequent clinical finding in children, and may be caused by intrinsic liver diseases or by systemic alterations, and in case of clinical suspicion, ultrasonography is generally the method of choice for pediatric patients (Rocha et al., 2009). Factors such as Age, sex, height, body weight, body surface area and alcohol consumption among males have been reported to exert an influence over liver size measured at the midclavicular line in a linear pattern (Kratzer et al., 2003; Ekpo et al., 2013; Ozmen et al., 2018).

Liver Vasculature and bile ducts of the liver are particularly well seen on ultrasound studies. Ultrasound can usually differentiate between non-obstructive and obstructive jaundice. Blood flow can be studied using colour flow Doppler, the direction and velocity of flow in the portal vein can be evaluated with pulsed wave Doppler (Palmar, 1998; Ryan, 2004). Budd-Chiari syndrome can also be well visualized using Doppler ultrasound (Sanders and Winter, 2007). In the standard practice every locality should have reference value for pediatrics liver dimensions and how it relates with anthropometric variables. However, literature review showed that there is no documented and published study on normal measurement of pediatrics liver dimensions by ultrasound and its relationship with anthropometric variables in Kano metropolis, Nigeria. The findings of this study will serve as a guide to the sonographers, radiologists and physicians in the diagnosis and management of pediatrics age group with pathologies that affect liver size. The study was aimed at evaluating liver dimensions and their correlation with anthropometric variables among apparently healthy pediatrics using ultrasonography in Kano metropolis, Nigeria.

\section{MATERIALS AND METHODS}

This was cross-sectional study conducted in some selected hospitals in Kano Metropolis, Nigeria, from May 2020 to August 2020. Ethical clearance was obtained from the research and ethical committee of the Kano State ministry of health in accordance with the Helsinki Declaration and informed consent was obtained either directly from the patient or indirectly from the patients' guardians. A simple random sampling method was employed; 426 apparently normal pediatric subjects were studied comprising of 213 males and 213 females within the age range of $0-<18$ years, the subjects were divided in to six age groups of $<28$ days, $>1$ month $<12$ month, 12 - 24month, $24-60$ month, 5 - 13years and 13 - 18years for both males and females involving 34, 34, 35, 35, 40 and 35 subjects respectively. The exclusion criteria included pediatric with recurrent malarial and typhoid fever, diabetic mother, major congenital anomaly, systematic illness such as cardiovascular, respiratory, neurological, and abdominal disease. All ultrasound scans were performed using Siemens SONOLINE Prima (Serial Number; BBE0617) diagnostic ultrasound system coupled with 3.5 $\mathrm{MHz}$ curvilinear transducer. Subject lie supine on the table, with the sonographer/sinologist on the right side of the subject. In a situation where by subject cannot comply may be due to anxiety he/she was reassured or supported by his/her relatives. The ultrasound gel was applied to the epigastric and right hypochondriac regions. The liver was examined with the patient in supine position. The left hepatic lobe was firstly screened in both longitudinal and 
transverse sections by continuous sweeping of transducer through the midline at the epigastric region to the level of the IVC. The right hepatic lobe was screened by applying the same sweeping motion of the probe from the midline to the right up to midclavicular or anterior axillary line. The patient was asked to get a deep breath were necessary. As described by Ekpo et al. (2013), the cranio-caudal liver dimension was obtained by also scanning through the mid clavicular and anterior axillary lines with longitudinal beam and slight oblique beams at the level in which the widest liver diameter is demonstrated. The anterior posterior dimension of liver was obtained by scanning through the mid-clavicular line inter-costally with a transverse beam and an inbuilt caliper was used to measure from the hepatic dome to the tip of the inferior angle. Both the antero-posterior and cranio-caudal dimensions were recorded in the data capture sheet. The sex, age, height and weight of each subject was also recorded in the data capture Sheet. The Body Mass Index (BMI) and Body Surface Area (BSA) were also calculated using the obtained height and weight.

$\mathrm{BMI}=$ Weight $(\mathrm{kg}) /$ height $\left(\mathrm{m}^{2}\right)$

$\mathrm{BSA}=\sqrt{\text { Height }}(\mathrm{cm}) \times$ weight $(\mathrm{kg}) / 3600$ (Mosteller formula)

\section{Statistical analysis}

Shapiro-Wilk test was used in carrying out the normality test on the obtained data and the data passed the test, therefore parametric data analysis was used. Both the descriptive and inferential statistics were employed for the data analysis. The mean, standard deviation and range were obtained using descriptive statistics. Pearson's correlation was used to correlate the liver dimension with the anthropometric variables. The data were analyzed using Statistical Package for the Social Sciences (IBM SPSS) Version 23.0. The statistical level of significance was set at $p<0.05$.

\section{RESULTS}

Four hundred and twenty-six pediatrics were studied out of which 213 were males and 213 were females. Among male pediatrics $34,34,35,35,40$ and 35 were in age group of <28days, $>1$ month <12months, 12 - 24months, 24 - 60months, 5 - 13years and 13 - 18years respectively. Also, among female pediatrics 34, 34, 35, 35, 40 and 35 were in age group of $<28$ days, $>1$ month <12months, 12 - 24months, $24-60$ months, 5 - 13years and 13 - 18years respectively.

Table 1: Demographics information of the males' subjects

\begin{tabular}{|c|c|c|c|c|c|}
\hline \multirow[t]{2}{*}{ Age groups } & \multicolumn{5}{|c|}{ Anthropometrics variables } \\
\hline & $\overline{\text { Age }}$ & $\begin{array}{l}\text { Height } \\
\text { (m) }\end{array}$ & $\begin{array}{l}\text { Weight } \\
\text { (Kg) }\end{array}$ & $\begin{array}{c}\text { BMI } \\
\left(\mathrm{Kg} / \mathrm{m}^{2}\right)\end{array}$ & $\begin{array}{l}\text { BSA } \\
\left(\mathrm{m}^{2}\right)\end{array}$ \\
\hline $\begin{array}{r}<28 \text { days } \\
(\mathrm{n}=34)\end{array}$ & $\begin{array}{c}12.71 \pm 7.74 \\
(1-26)\end{array}$ & $\begin{array}{r}0.57 \pm 0.05 \\
(0.50-0.70)\end{array}$ & $\begin{array}{c}3.62 \pm 0.70 \\
(2-5)\end{array}$ & $\begin{array}{c}11.39 \pm 2.29 \\
(7.56-16)\end{array}$ & $\begin{array}{c}0.23 \pm 0.03 \\
(0.16-0.29)\end{array}$ \\
\hline $\begin{array}{c}>1 \text { month } \\
<12 \text { months } \\
\quad(n=34)\end{array}$ & $\begin{array}{c}6.62 \pm 3.15 \\
\text { s } \quad(1-12)\end{array}$ & $\begin{array}{l}0.62 \pm 0.08 \\
(0.50-0.79)\end{array}$ & $\begin{array}{c}7.32 \pm 1.41 \\
(5-10)\end{array}$ & $\begin{array}{c}19.01 \pm 4.07 \\
(11.22-27.43)\end{array}$ & $\begin{array}{c}0.34 \pm 0.05 \\
(0.24-0.44)\end{array}$ \\
\hline $\begin{array}{l}12-24 \\
\text { months } \\
(\mathrm{n}=35)\end{array}$ & $\begin{array}{c}15.46 \pm 3.62 \\
(12-21)\end{array}$ & $\begin{array}{l}0.76 \pm 0.05 \\
\quad(0.69-0.85)\end{array}$ & $\begin{array}{r}9.80 \pm 1.86 \\
(6-14)\end{array}$ & $\begin{array}{l}17.05 \pm 2.63 \\
(11.07-22.45)\end{array}$ & $\begin{array}{l}0.44 \pm 0.05 \\
(0.34-0.53)\end{array}$ \\
\hline $\begin{array}{l}24-60 \\
\text { months } \\
(n=35)\end{array}$ & $\begin{array}{c}35.43 \pm 9.76 \\
\quad(24-54)\end{array}$ & $\begin{array}{l}0.88 \pm 0.09 \\
(0.67-1.07)\end{array}$ & $\begin{array}{c}12.09 \pm 2.02 \\
(9-16)\end{array}$ & $\begin{array}{c}15.73 \pm 2.21 \\
(11.45-20.00)\end{array}$ & $\begin{array}{l}0.53 \pm 0.07 \\
(0.39-0.64)\end{array}$ \\
\hline
\end{tabular}




$\begin{array}{lccccc}\mathbf{5 - 1 3} & 8.13 \pm 2.14 & 1.20 \pm 0.11 & 21.48 \pm 5.09 & 14.79 \pm 2.99 & 0.85 \pm 0.13 \\ \begin{array}{l}\text { years } \\ (\mathbf{n}=\mathbf{4 0})\end{array} & (5-12) & (1.00-1.48) & (13-30) & (10.71-22.73) & (0.60-1.11) \\ & & & & & \\ \mathbf{1 3 - 1 8} & 14.83 \pm 1.44 & 1.55 \pm 0.10 & 44.43 \pm 4.93 & 18.55 \pm 2.74 & 1.40 \pm 0.10 \\ \begin{array}{l}\mathbf{1 3 e a r s} \\ (\mathbf{n}=\mathbf{3 5})\end{array} & (13-17) & (1.31-1.75) & (33-55) & (12.41-28.27) & (1.11-1.61)\end{array}$

Table 2: Demographics information of the females' subjects.

\begin{tabular}{|c|c|c|c|c|c|}
\hline \multirow[t]{2}{*}{ Age groups } & \multicolumn{5}{|c|}{ Anthropometrics variables } \\
\hline & Age & $\begin{array}{l}\text { Height } \\
\text { (m) }\end{array}$ & $\begin{array}{l}\text { Weight } \\
\text { (Kg) }\end{array}$ & $\begin{array}{c}\text { BMI } \\
\left(\mathrm{Kg} / \mathrm{m}^{2}\right)\end{array}$ & $\begin{array}{l}\text { BSA } \\
\left(\mathrm{m}^{2}\right)\end{array}$ \\
\hline $\begin{array}{r}<28 \text { days } \\
(n=34)\end{array}$ & $\begin{array}{c}12.56 \pm 7.08 \\
(1-25)\end{array}$ & $\begin{array}{l}0.54 \pm 0.03 \\
(0.50-0.60)\end{array}$ & $\begin{array}{c}4.47 \pm 0.93 \\
\quad(3-6)\end{array}$ & $\begin{array}{c}15.15 \pm 3.01 \\
(8.62-21.36)\end{array}$ & $\begin{array}{l}0.25 \pm 0.03 \\
(0.20-0.30)\end{array}$ \\
\hline $\begin{array}{l}>1 \text { month }< \\
\text { 12months } \\
(n=34)\end{array}$ & $\begin{array}{l}6.44 \pm 3.04 \\
(1-11)\end{array}$ & $\begin{array}{c}0.63 \pm 0.06 \\
(0.50-0.76)\end{array}$ & $\begin{array}{l}7.56 \pm 1.33 \\
(5-10)\end{array}$ & $\begin{array}{c}19.27 \pm 3.28 \\
(13.01-26.45)\end{array}$ & $\begin{array}{l}0.34 \pm 0.05 \\
(0.26-0.42)\end{array}$ \\
\hline $\begin{array}{l}12-24 \\
\text { months } \\
(n=35)\end{array}$ & $\begin{array}{c}15.97 \pm 3.80 \\
(12-22)\end{array}$ & $\begin{array}{r}0.73 \pm 0.07 \\
(0.62-0.89)\end{array}$ & $\begin{array}{c}8.31 \pm 1.18 \\
(5-10)\end{array}$ & $\begin{array}{c}15.58 \pm 2.62 \\
(11.14-23.41)\end{array}$ & $\begin{array}{c}0.40 \pm 0.05 \\
(0.30-0.50)\end{array}$ \\
\hline $\begin{array}{l}24-60 \\
\text { months } \\
(n=35)\end{array}$ & $\begin{array}{l}38.20 \pm 10.11 \\
(24-56)\end{array}$ & $\begin{array}{c}0.89 \pm 0.07 \\
(0.75-1.05)\end{array}$ & $\begin{array}{c}12.66 \pm 1.68 \\
(9-15)\end{array}$ & $\begin{array}{l}16.15 \pm 2.06 \\
(10.17-19.56)\end{array}$ & $\begin{array}{l}0.55 \pm 0.06 \\
(0.46-0.66)\end{array}$ \\
\hline $\begin{array}{l}5-13 \\
\text { years } \\
(n=40)\end{array}$ & $\begin{array}{l}8.23 \pm 2.53 \\
(5-12)\end{array}$ & $\begin{array}{l}1.20 \pm 0.14 \\
(1.00-1.50)\end{array}$ & $\begin{array}{c}21.95 \pm 0.14 \\
(13-33)\end{array}$ & $\begin{array}{c}15.17 \pm 3.32 \\
(11.90-27.45)\end{array}$ & $\begin{array}{l}0.86 \pm 0.15 \\
(0.60-1.20)\end{array}$ \\
\hline $\begin{array}{l}13-18 \\
\text { years } \\
(n=35)\end{array}$ & $\begin{array}{c}14.80 \pm 1.51 \\
(13-17)\end{array}$ & $\begin{array}{l}1.52 \pm 0.12 \\
(1.29-1.76)\end{array}$ & $\begin{array}{c}42.51 \pm 5.90 \\
(34-57)\end{array}$ & $\begin{array}{c}18.73 \pm 3.16 \\
(12.25-23.63)\end{array}$ & $\begin{array}{l}1.34 \pm 0.12 \\
(1.11-1.61)\end{array}$ \\
\hline
\end{tabular}

Table 3: Mean \pm SD of liver dimensions among both male and female pediatrics.

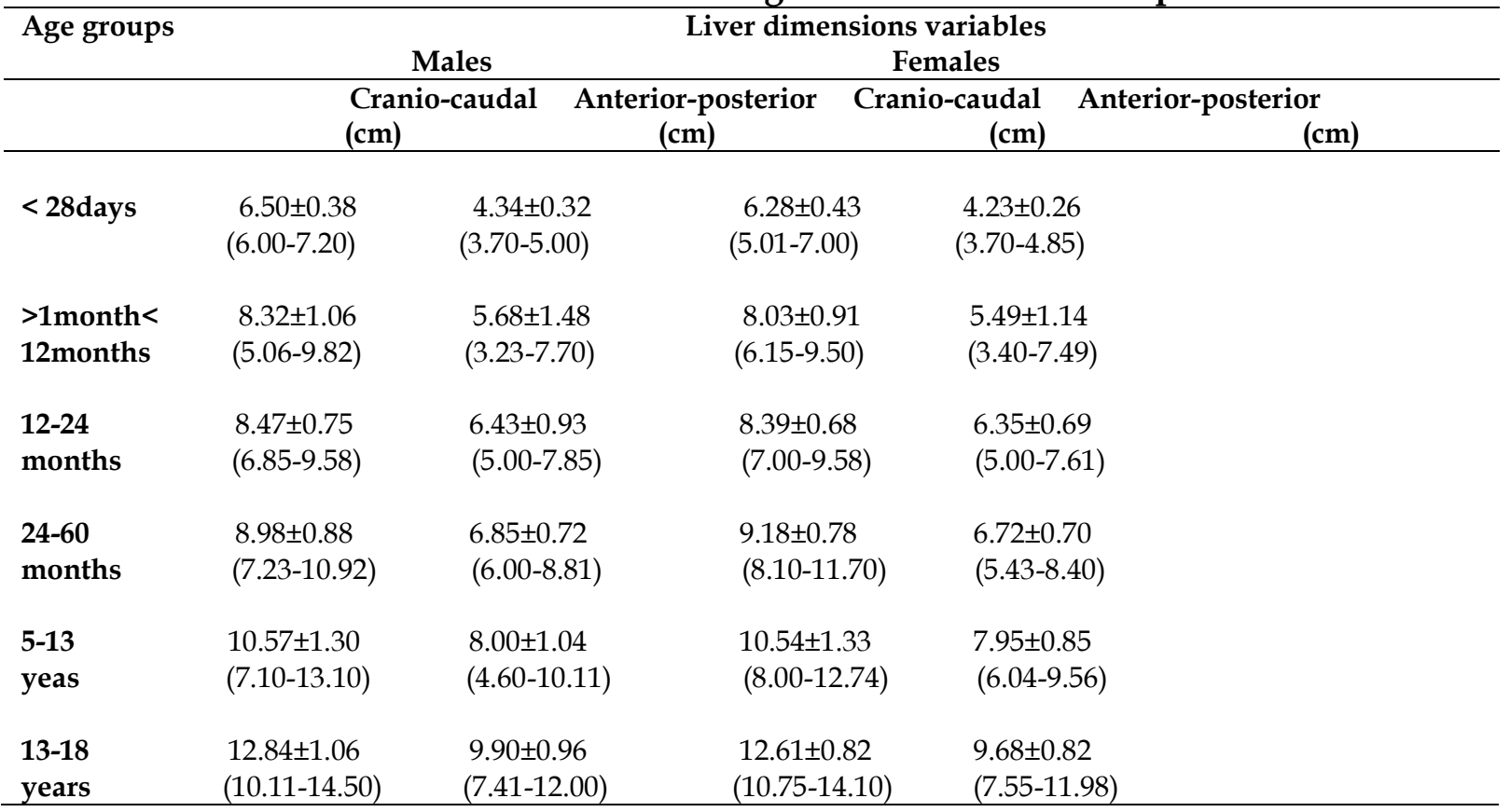


Table 4: Correlation of Cranio-caudal dimension and anthropometrics variables in male subjects.

\begin{tabular}{|c|c|c|c|c|c|c|c|c|c|c|c|}
\hline \multirow[t]{3}{*}{ Age groups } & & \multicolumn{10}{|c|}{ Anthropometrics variables } \\
\hline & & \multicolumn{2}{|c|}{ Age } & \multicolumn{2}{|c|}{ Height } & \multicolumn{2}{|c|}{ Weight } & \multicolumn{2}{|c|}{ BMI } & \multicolumn{2}{|c|}{$\overline{\text { BSA }}$} \\
\hline & & $\mathrm{r}$ & $p$ & $\mathrm{r}$ & $p$ & $\mathrm{r}$ & $p$ & $\mathrm{r}$ & $p$ & $\mathrm{r}$ & $p$ \\
\hline$<28$ days & 0.70 & 0.000 & 0.66 & 0.000 & 0.38 & 0.027 & 0.55 & 0.001 & 0.69 & 0.000 & \\
\hline$>1-<12$ month & 0.74 & 0.000 & 0.86 & 0.000 & 0.64 & 0.000 & 0.74 & 0.000 & 0.53 & 0.001 & \\
\hline 12 - 24months & 0.33 & 0.051 & 0.15 & 0.400 & 0.38 & 0.024 & 0.21 & 0.236 & 0.38 & 0.023 & \\
\hline $24-60$ months & 0.55 & 0.001 & 0.54 & 0.001 & 0.48 & 0.004 & 0.43 & 0.010 & 0.54 & 0.001 & \\
\hline 5 - 13years & 0.53 & 0.000 & 0.38 & 0.017 & 0.33 & 0.035 & 0.28 & 0.079 & 0.55 & 0.000 & \\
\hline 13 - 18years & 0.47 & 0.004 & 0.40 & 0.018 & 0.10 & 0.586 & 0.06 & 0.729 & 0.22 & 0.209 & \\
\hline
\end{tabular}

Table 5: Correlation of Anterior-posterior dimension and anthropometrics variables in male subjects

\begin{tabular}{|c|c|c|c|c|c|c|c|c|c|c|c|}
\hline \multirow[t]{3}{*}{ Age groups } & & \multicolumn{10}{|c|}{ Anthropometrics variables } \\
\hline & & \multicolumn{2}{|c|}{ Age } & \multicolumn{2}{|c|}{ Height } & \multicolumn{2}{|c|}{ Weight } & \multicolumn{2}{|c|}{ BMI } & \multicolumn{2}{|c|}{ BSA } \\
\hline & & $\mathrm{r}$ & $p$ & $\mathrm{r}$ & $p$ & $\mathrm{r}$ & $p$ & $\mathrm{r}$ & $p$ & $\mathrm{r}$ & $p$ \\
\hline$<28$ days & 1.00 & 0.000 & 0.05 & 0.801 & -0.25 & 50.149 & 0.44 & $4 \quad 0.009$ & 0.46 & 0.007 & \\
\hline$>1-<12$ month & 0.42 & 0.013 & -0.29 & 0.101 & -0.47 & 0.005 & 0.67 & 0.000 & 0.67 & 0.000 & \\
\hline 12 - 24months & 0.14 & 0.427 & 0.08 & 0.644 & -0.04 & 0.820 & 0.43 & 0.010 & 0.18 & 0.291 & \\
\hline $24-60$ months & 0.37 & 0.028 & -0.04 & 0.818 & -0.14 & 0.417 & 0.55 & 0.001 & 0.44 & 0.009 & \\
\hline 5 - 13years & 0.41 & 0.009 & 0.39 & 0.014 & 0.23 & 0.158 & 0.51 & 0.001 & 0.39 & 0.012 & \\
\hline 13 - 18years & 0.21 & 0.237 & 0.06 & 0.724 & 0.08 & 0.641 & 0.20 & 0.240 & 0.17 & 0.317 & \\
\hline
\end{tabular}

Table 6 Correlation of Cranio-caudal dimension and anthropometrics variables in female subjects

\begin{tabular}{|c|c|c|c|c|c|c|c|c|c|c|c|}
\hline \multirow[t]{3}{*}{ Age groups } & & \multicolumn{10}{|c|}{ Anthropometrics variables } \\
\hline & & \multicolumn{2}{|c|}{ Age } & \multicolumn{2}{|c|}{ Height } & \multicolumn{2}{|c|}{ Weight } & \multicolumn{2}{|c|}{ BMI } & \multicolumn{2}{|c|}{ BSA } \\
\hline & & $\mathrm{r}$ & $p$ & $\mathrm{r}$ & $p$ & $\mathrm{r}$ & $p$ & $\mathrm{r}$ & $p$ & $\mathrm{r}$ & $p$ \\
\hline$<28$ days & 0.63 & 0.000 & 0.41 & 0.015 & -0.03 & 0.890 & 0.27 & 0.129 & 0.41 & 0.015 & \\
\hline$>1-<12$ month & 0.60 & 0.000 & 0.61 & 0.000 & 0.59 & 0.000 & 0.81 & 0.000 & 0.66 & 0.001 & \\
\hline 12 - 24months & 0.50 & 0.002 & 0.22 & 0.195 & 0.51 & 0.002 & 0.40 & 0.018 & 0.27 & 0.122 & \\
\hline 24 - 60months & 0.54 & 0.001 & 0.47 & 0.004 & 0.46 & 0.006 & 0.30 & 0.082 & 0.40 & 0.019 & \\
\hline 5 - 13years & 0.60 & 0.000 & 0.55 & 0.000 & 0.62 & 0.000 & 0.41 & 0.008 & 0.73 & 0.000 & \\
\hline 13 - 18years & 0.71 & 0.000 & 0.61 & 0.000 & 0.27 & 0.116 & 0.18 & 0.290 & 0.61 & 0.000 & \\
\hline
\end{tabular}

Table 7: Correlation of Anterior-posterior dimension and anthropometrics variables in female subject

Age groups

Anthropometrics variables

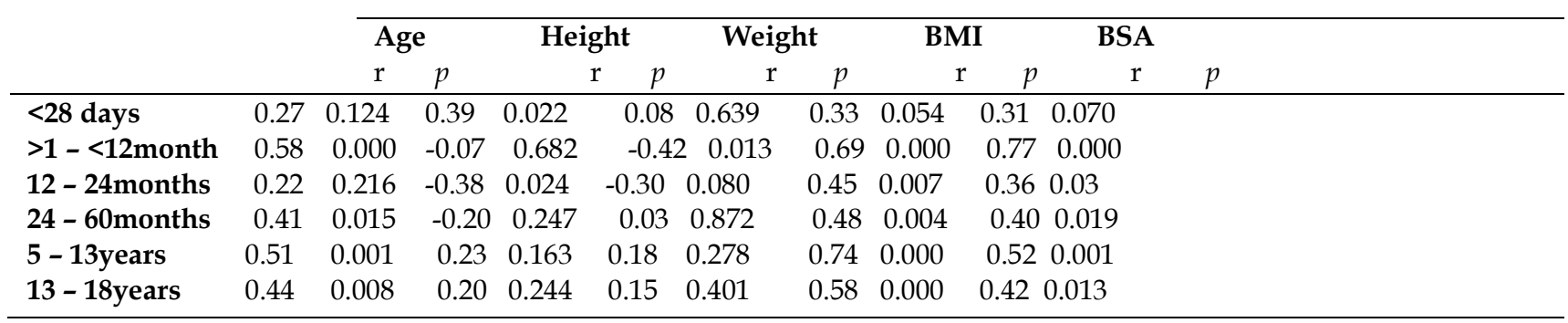



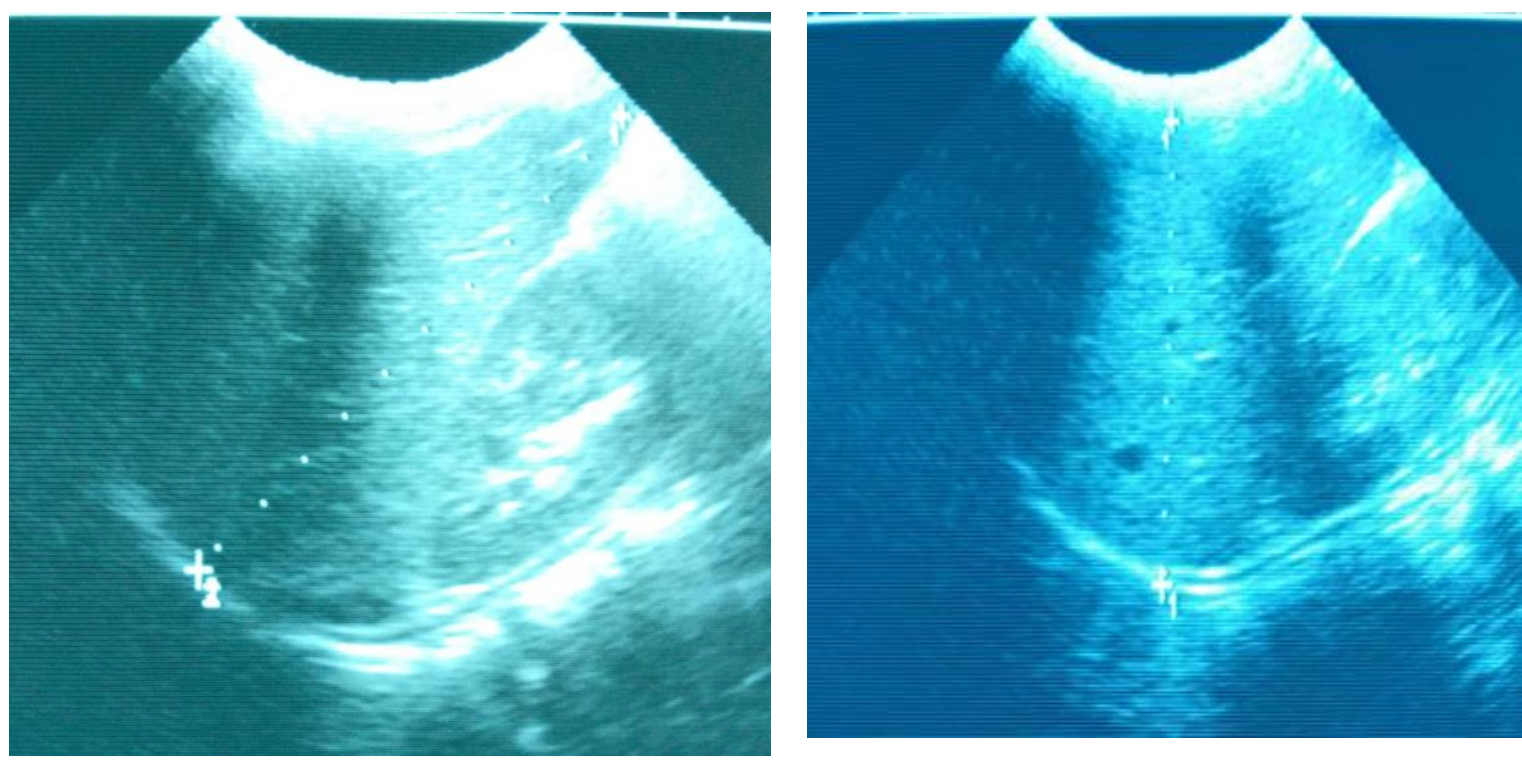

Plate 1: Shows cranio-caudal and antero-posterior liver dimension of apparently normal 12years old male pediatric.

\section{DISCUSSION}

The findings of the current study as shown in Table 1 and 2 was contrary to the findings of previous studies by Umeh et al. (2015) who reported mean of male subjects' age, height and weight of 76.19 months; $113.05 \mathrm{~cm}$ and $20.89 \mathrm{Kg}$ respectively while for female subjects 71.68 months; $111.05 \mathrm{~cm}$ and $18.69 \mathrm{Kg}$ respectively. Weerakul et al. (2011) reported the mean of the subjects' weight, height and BSA of $8.81 \mathrm{~kg} ; 71.1 \mathrm{~cm}$ and $0.28 \mathrm{Kg} / \mathrm{m}^{2}$ respectively. While Dhingra et al. (2009) and Thapa et al. (2015) reported the mean \pm SD of the subjects' age of 56.5months and 45.78 months respectively. The reason for the differences may be due to the fact that, all these previous studies did not sub-divide their subjects in to different age groups and compute for the mean \pm SD of age, height, weight, BMI and BSA independently. As shown in Table 3, the findings of the current study was similar to the findings of the previous study by Dhingra et al. (2009) who reported that, the mean \pm SD of liver span for male subjects within the group of $1-<3$ months, $3-<6$ months, $6-<12$ months, $1-<2$ years, 2 - <4years, $4-<$ 6years, $6-<$ 8years, $8-<10$ years and $10-<12$ years were $6.5 \pm 1.23 \mathrm{~cm} ; 7.1 \pm$ $0.77 \mathrm{~cm} ; 7.5 \pm 0.88 \mathrm{~cm} ; 8.6 \pm 0.85 \mathrm{~cm} ; 9.0 \pm 1.34 \mathrm{~cm} ; 10.3 \pm 1.27 \mathrm{~cm} ; 10.8 \pm 0.94 \mathrm{~cm} ; 11.9 \pm 1.08 \mathrm{~cm}$ and $12.6 \pm 1.20 \mathrm{~cm}$ respectively, while, for female subjects within the same age group were $6.2 \pm 0.66 \mathrm{~cm} ; 7.2 \pm 0.94 \mathrm{~cm} ; 7.9 \pm 0.92 \mathrm{~cm} ; 8.5 \pm 1.51 \mathrm{~cm} ; 8.9 \pm 0.97 \mathrm{~cm} ; 9.8 \pm 1.29 \mathrm{~cm} ; 10.9 \pm$ $1.29 \mathrm{~cm} ; 11.7 \pm 1.11 \mathrm{~cm}$ and $12.3 \pm 1.39 \mathrm{~cm}$ respectively. This similarity may be because similar methods of study and study design were used. These findings were similar to those of Thapa et al. (2015) who reported that, the mean \pm SD of liver span of the subjects in 1 6months, 7 -12months, 13 - 18months, 19 - 24months, 24 - 48months, 49 - 72months, 6 7years, 7 - 10years, $10-12$ years and $12-1$ yyears were $6.88 \pm 0.70 \mathrm{~cm} ; 7.65 \pm 0.93 \mathrm{~cm} ; 8.35 \pm$ $0.62 \mathrm{~cm} ; 8.50 \pm 0.85 \mathrm{~cm} ; 8.73 \pm 0.89 \mathrm{~cm} ; 9.12 \pm 0.83 \mathrm{~cm} ; 9.31 \pm 0.99 \mathrm{~cm} ; 9.87 \pm 0.87 \mathrm{~cm} ; 10.63 \pm$ $1.07 \mathrm{~cm}$ and $11.61 \pm 0.88 \mathrm{~cm}$ respectively. This similarity was observed despite the fact that they reported a combine means representing both male and female subjects. Similar research methods and pediatric age range with the current study may be the reason for the similarity. Furthermore, the findings of the current study was contrary to the findings by Weerakul et al. (2011) who reported that, the mean liver span for male subjects within the age group of $<3$ months, 3 -6months, 6 - 9months, 9 -12months, 12 - 18months and $18-24$ months were $4.3 \mathrm{~cm}, 4.9 \mathrm{~cm}, 5.3 \mathrm{~cm}, 5.5 \mathrm{~cm}, 6.2 \mathrm{~cm}$ and $6.8 \mathrm{~cm}$ respectively while, for female subjects within the same age group were $4.3 \mathrm{~cm}, 4.8 \mathrm{~cm}, 5.1 \mathrm{~cm}, 5.6 \mathrm{~cm}, 5.6 \mathrm{~cm}$ and $6.4 \mathrm{~cm}$ respectively. This difference may be due to racial, dietary or environmental differences. Also, the findings of 
the current study contradicted the findings by Amatya et al. (2013) who reported that, the mean \pm SD of the subject's liver span in $0-2$ months, $2-12$ months, 1 - 5years, 5 - 10years and $10-15$ years were $5.32 \pm 0.52 \mathrm{~cm}, 6.44 \pm 0.42 \mathrm{~cm}, 8.91 \pm 0.86 \mathrm{~cm}, 9.29 \pm 0.91 \mathrm{~cm}$ and $10.70 \pm$ $1.11 \mathrm{~cm}$ respectively. Likewise, Umeh et al. (2015) reported that, the mean \pm SD of liver span of male and female subjects was $12.78 \pm 13.7 \mathrm{~cm}$ and $10.62 \pm 1.1 \mathrm{~cm}$ respectively. The differences may be because of racial and environmental differences and the research method used by Amatya et al. (2013) differ from that used in this current study.

The findings of the current study as shown in Table 4 and 6 was similar to the findings by Konus et al. (1998) who reported a strong positive correlation in male and female subjects between longitudinal dimension of the liver and weight, age, height and body surface area: $(\mathrm{r}=0.85) ;(\mathrm{r}=0.82),(\mathrm{r}=0.80)$ and $(\mathrm{r}=0.83)$ respectively. The similarity may be due to the fact that both studies adopted the same scanning technique in liver measurements. Furthermore, Konus et al. (1998) found out that there was strong positive correlation in male and female subjects between anterior-posterior dimension of the liver and weight, age, height and body surface area: $(\mathrm{r}=0.77) ;(\mathrm{r}=0.71) ;(\mathrm{r}=0.73)$ and $(0.75)$ respectively. This was contrary to findings of the current study as shown in Table 5 and 7 except between antero-posterior liver dimension and BMI and BSA which showed strong significant positive correlation. The reason for the differences may be due to technical, geographical, socioeconomic and racial differences. This is because using different scanning approach for example measuring liver dimension at either mid-axillary or midclavicular line may yield different liver value. Furthermore, similar to the findings of the current study was the study by Sripriya et al. (2017) who reported a significant positive correlation in both male and female subjects between liver dimension and height, weight and age: $(\mathrm{r}=0.89, \mathrm{p}=0.000) ;(\mathrm{r}=0.86, \mathrm{p}=0.000)$ and $(\mathrm{r}=0.90, \mathrm{p}=0.000)$ respectively, despite the fact that only cranio-caudal dimension was considered by Sripriya et al. (2017). The similarity may be because they adopt the same scanning technique and research method. More so, among studies that reported correlation of liver span with age, height, weight and BSA were studies by Thapa et al. (2015) who reported that there was a strong positive correlation in both male and female subjects between liver dimension and age, weight and height: $(r=0.81) ;(r=0.74)$ and $(r=0.78)$ respectively; Amatya et al. (2013) who reported that there was a strong positive correlation in both male and female subjects between liver span and age, weight, height and BSA: $(\mathrm{r}=0.87) ;(\mathrm{r}=0.86) ;(\mathrm{r}=0.92)$ and $(\mathrm{r}=0.90)$ respectively; Weerakul et al. (2011) who revealed that there was a strong positive correlation in both male and female subjects between liver dimension and age, weight, height \& BSA: $(r=0.748) ;(r=0.747) ;(r=0.760)$ and $(r=0.764)$ respectively; and Rocha et al. (2009) revealed that there was a strong positive correlation in both male and female subjects between liver dimension and age, height \& weight: $(\mathrm{r}=0.80$, $\mathrm{p}=0.000) ;(\mathrm{r}=0.85, \mathrm{p}=0.000)$ and $(\mathrm{r}=0.82, \mathrm{p}=0.000)$ respectively. These was similar to the finding of the current study as shown in Table 4 and 6; however, the correlation was weak and not significant among old pediatrics, these similarities may be due to similarity in scanning technique and research method.

\section{CONCLUSION}

This study showed that, age, BMI and BSA is positively correlated to both cranio-caudal and antero-posterior liver dimensions. Furthermore, cranio-caudal also is positively correlated to the height. 


\section{REFERENCES}

Amatya, P., Shah, D., Gupta, N., Bhatta, N, K. (2013), 'Clinical and ultrasonographic measurement of liver size in normal children', Indian Journal of Pediatrics; 81(5): 441 445 .

Dhingra, B., Sharma, S., Mishra, D., Kumari, R., Pandey, R, M. et al. (2009), 'Normalvalues of liver and spleen size by ultrasonography in Indian children', Indian journal of Pediatrics; 47: 487 - 492.

Ekpo, E, U., Ikamaise, V, C., Egbe, N, O., Akwa, E, E., Eyo, B, A. (2013), 'Sonographic correlation of liver dimension and anthropometric variables of height, weight and body mass index', Journal of Association of Radiographers of Nigeria; 27(1): 25 - 31.

Konus, O, L., Odezmir, A., Akkaya, A., Erbas, G., Celik, H., et al. (1998), 'Normal Liver, Spleen, and Kidney Dimensions in Neonates, Infants, and Children: Evaluation with Sonography', American Journal of Radiology; 171: 1693 - 1698.

Kratzer, W., Fritz, V., Mason, R, A., Haenle, M, M., Kaechele, V., Roemerstein Study Group. (2003), 'Factor affecting liver size: A sonographic survey of 2080 subjects', J Ultrasound Med; 22: 1155 - 1151.

Lissauer, T., Clayden, G., Craft, A. (2015), 'Illustrated textbook of pediatrics'. 1 ${ }^{\text {st }}$ Edn, Edinburgh: Mosby.

Ozmen, Z., Aktas, F., Ozmen, Z, C., Almus, E., Demir, O. (2018), ‘Ultrasound measurement of liver longitudinal length in North Anatolian population: A community-based study', Niger J Clin Pract; 21: 653 - 657.

Palmer, P. (1998) 'Manual of diagnostic ultrasound' Geneva 1998: World Health Organization. www.who.com. [Last Accessed on December 15th 2020]

Rocha, S, M, S., Ferrer, A, P, S., Oliveira, I, R, S., Widman, A., Chammas, M, C. et al. (2009), 'Sonographic determinationa of liver size in healthy newborns, infants and children under 7years of age' Radiol Bras; 42(1): 7 - 13.

Ryan, S. (2004), 'Anatomy for diagnostic imaging' 2nd Edn, Philadelphia: Elsevier.

Sanders, R, C., Winter. (2007), 'Clinical sonography a practical guide' $4^{\text {th }}$ Edn, Philadelphia: Lippincott Williams \& Wilkins.

Sembulingam, K., Sembulingam, P. (2012), 'Essentials of medical physiology'. $6^{\text {th }}$ Edn, New Delhi: Jaypee Brothers Medical Publishers.

Sripriya, R., Karthick, A, R., Natarajan, Gangadharan, S. (2017), 'Clinical and Ultrasonographic Assessment of Liver Span in Children', Journal of Medical Science and Clinical Research; 51(8): 26339 - 26344

Thapa, N, B,. Shah, S., Pradhan, A., Rijal, K., Pradhan, A. et al. (2015), 'Sonographic assessment of the normal dimensions of liver, spleen, and kidney in healthy children at tertiary care hospital', Kathmandu University Medical Journal; 13(4): 286 - 291.

Umeh, E., Adeniji-Sofoluwe, A, T., Adekanmi, A, J., Atalabi, O, M. (2015), 'Normal sonographic dimensions for liver, spleen and kidneys in healthy south west Nigerian children-a pilot study', West African Journal of Ultrasound; 16: 1 - 7.

Weerakul, J., Galassi, W., Chaiyakunapruk, N. (2011), 'Physical and ultrasonographic estimation of liver size in healthy Thai children under two years old', Asian Biomedicine; 5 (3): 403 - 406. 